\title{
Enforcement Deterrence In Tackling Haze Pollution: Insight From In-Depth Interview
}

\author{
Firman Tatariyanto \\ firmantatariyan@fuji.waseda.jp \\ Graduate School of Asia Pacific Studies - Waseda University, 1-chome-21-1 Nishiwaseda Shinjuku \\ Japan
}

\begin{abstract}
Reaching a better understanding of the enforcement of current regulatory approaches will provide a baseline for enhancing future policy choices for deterring and controlling the devastating effects of haze pollution. Using in-depth interviews with prominent actors who have direct and indirect involvement on the law enforcement process, this paper investigates how insufficient power and law enforcement capacity could hamper and deter policies for tackling haze pollution. The paper shows that an inadequate probability of detection for environmental offenses, especially in South Sumatra, causes economic agents to incorrectly receive signals to not engage in unsustainable and illegal activities. More specifically, the paper finds that the absence of a special arrangement for the recovery of environmental costs and direct financial mechanisms for how fines would be utilized has been hampering law enforcement. The establishment of a policy regime that is inclusive of fiscal provisions in mixed environmental management cannot be overlooked as a reference point for effective future solutions.
\end{abstract}

Keywords: Deterrence, enforcement, haze pollution

\section{Introduction}

The palm oil plantation and industrial processing sector have been one of the leading sectors for the development of the Indonesian economy. However, at the same time, the Indonesian plantation sector has also been identified as the most significant driver of forest and peatland clearing, which creates major haze pollution and is a source of greenhouse emissions [1], [2]. The burnt areas that create haze pollution within the Riau and South Sumatra Provinces are in company concession areas [3],[4]. Moreover, in the agricultural process, people use burning to clear and convert the land for palm oil plantation [5],[6],[7],[8]. Unfortunately, the clearing is also in the peatland area, and the fire spread out of control, creating peatland burning [9]. Peat fires are producing a large amount of smoke and contributing to a massive fraction of pollutant emissions factors in the atmosphere, in the end, causing health problems [10], [11]. Even a low intensity of peatland burning will produce significant emissions of pollution [10].

Haze pollution is defined as smoke resulting from land and forest fires, which cause deleterious effects that endanger human health; harm living resources, ecosystems and material property; and impair or interfere with amenities and other legitimate uses of the environment [12]. The government of Indonesia has enacted command and control regulations for tackling the haze pollution issue but with limited success and a lack of public trust. Please 
see: [13],[14]. The need for regulatory enforcement policies that deter and control emissions by increasing the responsibility of the economic agents that pollute the environment is inevitable for future policy choices.

By focusing on the enforcement deterrence, this paper primarily aims to identify the state of implementation of current policies, especially enforcement obstacles for land/forest fires, through the perceptions of actors. Deterrence theory draws on a rational choice phenomenon in which an economic agent is assumed to weigh the costs and benefits of an action to avoid a sanction; when the likelihood of detection and punishment outweighs the benefits, a deterrent effect can be observed [15]. Understanding how to enhance deterrence is vital because in regulatory enforcement studies, improving enforcement in a country where the governmental capacity is limited and societal support is emerging is a puzzling task [16], [17].

Simorangkir and Sumatri [18] stated that the weak enforcement of laws and regulations is becoming the biggest problem in managing Indonesia's land and forest fires. Carmenta [19] analyzed the perceived effectiveness of Fire Management Interventions using the Q method to quantify contention and consensus among stakeholders. In the hard measures against substantial actor factors, the enforcement of diverse Fire Management Interventions, including sanctions, would be preferred as an effective solution. Even though there are discrepancies related to the sources of fires, the findings reveal that there is a need to move from an oversimplification of fire phenomena and blaming for setting fires to multistakeholder policy engagement that considers the environment, the economy, and health. Furthermore, Budiningsih [4] showed that a lack of coordination among governmental agencies was less than optimal in the context of fire suppression.

Based on existing studies of land/forest fires in Indonesia, this paper extends the results of Carmenta [19] and follows the study of Matland [20] by distinguishing the obstacles in the regulatory enforcement process, including the implementation of policies and within internal enforcement agencies. To the best of our knowledge, no previous study on environmental policies has considered deterrence from the perspective of law enforcement actors for the study areas of the Riau and South Sumatra Provinces. This paper addresses the following question: how does insufficient power and law enforcement capacity hamper deterrence in South Sumatra and Riau Provinces?

The actor perspective, consisting of both internal and external stakeholders and including regulatory enforcement policies to address deterrence, is critical for improving the design of policies and on-the-ground implementation [21], [22]. Furthermore, actor insights can provide a valuable piece of the puzzle in helping to focus on primary problems [23].

The remainder of the paper is structured as follows. Section 2 discusses the in-depth interview analysis and study area selection. Section 3 presents the interview results, followed by the research findings and discussion. Section 4 contains the conclusions and highlights possible future policy options for tackling haze pollution.

\section{Methods}

The paper uses in-depth interview analysis, a technique that includes intensive individual interviews with a few respondents to elaborate on their perspectives, in the context of detecting possible risk deterrence issues. Moreover, these interviews were designed to be semistructured, with open-ended questions funneling the discussion from general law enforcement experience in land/forest fires to the incidence of hotspots and a discussion of 
obstacles to the enforcement of deterrence. Once the obstacles have been discussed, the respondent is asked to describe, in more detail, their subjective perceptions about the nature of the obstacles, especially in the context of political implementation and regulatory capacity. Follow-up questions then stimulate discussion with the respondent and a spontaneous inquiry about the probability of enhancing deterrence. Using qualitative in-depth interviews allows for a broader subjective understanding of deterrence that includes the detection of perceptions and the severity of sanctions. The interviews were conducted in Bahasa (the formal language of Indonesia), and supporting data were gathered through fieldwork in the Riau and South Sumatra Provinces in Indonesia during October 2018.

The Riau and South Sumatra Provinces were selected as a background of the study because they provide opportunities to observe the complexities of haze pollution in Indonesia. First, the Riau and South Sumatra Provinces are among the 14 provinces in Indonesia located on Sumatra Island, which has been profoundly influenced by the occurrence of hotspots. Second, both provinces have been critical in exposing the natural forest through land-use changes and forest destruction. The 2017 land cover quality index ${ }^{1}$ (Indeks Kualitas Tutupan Lahan) values for both provinces is among the lowest on Sumatra Island, with 51.89\% for Riau Province and $42.55 \%$ for South Sumatra Province. On the other hand, the National Peatland Ecosystem Areas $^{2}$ in the Riau and South Sumatra Provinces are the largest areas on Sumatra Island at $5,042,561 \mathrm{Ha}$ and 1,955,103 Ha, respectively. Previous studies have shown that aggressive human-made burning practices to clear and convert the land for palm oil plantations, especially in peatland, are a driving factor for haze pollution [7], [8].

During the interviews, the conversations were recorded after obtaining permission from the interviewees through written consent. Notes were also taken to complement and emphasize the critical points expressed by the respondents. The respondents were selected from among various law enforcement stakeholders to enable the elaboration of different perspectives. Please refer to Table 1 . The interviews started with prominent representatives who have direct involvement in the law enforcement process, namely, an Investigator and a Prosecutor who handle cases in the Riau and South Sumatra Provinces. The Investigator is a Police and Government Official (i.e., an Investigator in the Ministry of Environment and Forestry and Local Government) who has been given exclusive authority by law ${ }^{3}$ to conduct investigations.

Moreover, the Prosecutor is a Public Prosecutor who is authorized by law to conduct prosecutions in the courtroom and execute the decisions of judges ${ }^{4}$. Furthermore, we interviewed an Expert who gives statements in the courtroom related to land and forest fire cases $^{5}$ and people in a Non-Governmental Organization (NGO) who independently monitor the law enforcement process, specifically for haze pollution in Indonesia.

\footnotetext{
1 The index describes the condition of the surface appearance of physical land in terms of both the natural appearance in the form of vegetation and the human-made appearance. The quality of the land cover is currently measured by the existing forest as one of the crucial components in the ecosystem.

2 Based on the Ministry of Environmental and Forestry Decree No. SK.130/MENLHK/SETJEN/PKL.0/2/2017 on Establishment Map of National Peatland Ecosystem Function

${ }^{3}$ Article 6, Law Number 8 / 1981 on Criminal Law.

${ }^{4}$ Article 13, Law Number 8 / 1981 on Criminal Law.

${ }^{5}$ Article 186, Law Number 8 / 1981 on Criminal Law.
} 
Due to interviewees were the critical determinant of the data and to reduce the interview biased law enforcement representatives were selected for interviews based on the endorsement of their respective office, which assigned a specific officer as a respondent for the in-depth interview. Unfortunately, the Riau Local Environmental Agency did not respond to inquiries related to conducting the research. The selected enforcement officers were knowledgeable and experienced in enforcing environmental externalities, especially for haze pollution. Moreover, another respondent, from NGO and expert, is selected based on capabilities and personal attributes in the case of haze pollution.

The interview data were coded using Microsoft Excel and Word. The raw interviews were analyzed by developing a raw table of important aspects and a summary of the interviewees' answers. Each important aspect of the study was organized and coded.

Table 1. Profile of Respondents

\begin{tabular}{|c|c|c|}
\hline ID & Respondent & Role \\
\hline D-1-RPolice & Riau Regional Police & Investigator \\
\hline D-7-SSPolice & South Sumatra Regional Police & Investigator \\
\hline D-2-RAttorney & Riau High Attorney General & Prosecutor \\
\hline D-6-SSAttorney & South Sumatra High Attorney General & Prosecutor \\
\hline D-5-SSLocalEA & South Sumatra Local Environmental Agency & Investigator \\
\hline D-3-MinEAF & Ministry of Environmental and Forestry & Investigator \\
\hline D-4-ExpertW & $\begin{array}{l}\text { Professor in Forest Fire from Bogor } \\
\text { Agricultural University }\end{array}$ & Expert in Criminal Court \\
\hline ID-2-EnvNGO & Coordinator - JIKALAHARI & $\begin{array}{l}\text { Non-Governmental } \\
\text { Organization }\end{array}$ \\
\hline ID-3-EnvNGO & Executive Director - Green Trade Initiative & $\begin{array}{l}\text { Non-Governmental } \\
\text { Organization }\end{array}$ \\
\hline ID-4-EnvNGO & Forest Campaigner - GREENPEACE & $\begin{array}{l}\text { Non-Governmental } \\
\text { Organization }\end{array}$ \\
\hline
\end{tabular}

\section{Results and Discussion}

\subsection{The Incidence of Hotspots in Indonesia}

In the first part of this chapter, the paper discusses the points of view of the respondents as they relate to the nature of hotspots. The subjective knowledge of respondents in identifying the primary source of a land/forest fire is becoming an essential foundation for building enforcement policies.

An Investigator from the Ministry of Environmental and Forestry (D-3-MinEAF) argued that the fires in Indonesia are $100 \%$ triggered by humans. He believed that the tropical rainforest in Indonesia, compared to the temperate forest, is unlikely to burn naturally. Moreover, the Investigator from the Riau Regional Police (D-1-RPolice) stated that based on legal fact-finding during criminal investigations, land/forest fires are deliberately initiated by palm oil companies and smallholder plantation farmer. The Expert in the criminal court for haze pollution cases from Bogor Agriculture University (D-1-ExpertW) stated that $99.9 \%$ of fires are triggered by humans, and in most cases, cigarettes and mosquito repellent, which are 
used as a timer, are connected to a matchstick starter and placed in a stack of wood and branches that have been cut down. The Forest Campaigner from Greenpeace (ID-4-EnvNGO) argued that land forest fires in the peat areas are mainly caused by changes in the land-use change to plantations by extensive peatland draining through the opening of canals.

In contrast, the paper also identified a counternarrative related to intentional land and forest fires from South Sumatra Regional Police Investigator (D-7-SSPolice), who made the following argument:

Investigator: In my opinion, there is no intentionally burning except by smallholders who use fire to efficiently clear their plantation. Moreover, it is unlikely for a palm oil plantation to carry out a deliberate burning because it will result in the loss of productive palm oil trees that burn down.

With regard to further detail on the area of burning, the coordinator of JIKALAHARI, an Environmental NGO based in Riau (ID-2-EnvNGO), stated that most of the fires in Riau Province occur inside the concessions of companies. Table 2 shows the Plantation Companies that have HGUs and IUPHHK with fires occurrence in their concession areas during 20152017 in Riau Province. In 2017, seven companies with HGU, or 54\% of the companies, had three consecutive years of burning on their land. A total of 65 companies with IUPHHK had burned land in 2017, and $82 \%$ of the land of 53 companies burned during the 2015-2017 period. As a result, the coordinator argued that plantation companies should be responsible for maintaining and extinguishing fires on their concession areas.

Table 2. Hotspots in Concession Area - Riau Province

\begin{tabular}{ccc|cc}
\hline \multicolumn{2}{c|}{ Hotspot in Concession Area } & \multicolumn{2}{c}{$\begin{array}{c}\text { Number Repeated Companies with } \\
\text { Concession Area that has the Hotspot (3 } \\
\text { Years Observation) }\end{array}$} \\
\cline { 2 - 5 } & $\begin{array}{c}\text { Hotspot } \\
\text { Number of } \\
\text { Company } \\
\text { HGU) }\end{array}$ & $\begin{array}{c}\text { Hotspot (Number } \\
\text { of Company } \\
\text { IUPHHK) }\end{array}$ & $\begin{array}{c}\text { HGU - Repeated } \\
\text { Hotspot - 2 Years } \\
\text { (3 Years) }\end{array}$ & $\begin{array}{c}\text { IUPHHK Repeated } \\
\text { Hotspot-2 Years (3 } \\
\text { Years) }\end{array}$ \\
\hline 2015 & $389(41)$ & $3,641(108)$ & $12(7)$ & $23(53)$ \\
2016 & $111(21)$ & $1,859(76)$ & & \\
2017 & $28(13)$ & $902(65)$ & & \\
\hline
\end{tabular}

In general, the first finding on the nature of hotspots shows that almost all respondents agreed that the land/forest fires that create haze pollution are triggered by intentional human action to clear and convert land for palm oil plantations, consistent with previous studies. Please see: [6], [7], [8]. However, the interviews also reveal a different law enforcement perspective related to the nature of fires, which is critical in the context of gaining a common understanding of officer perceptions about potential responsibility and observable policy implementation gaps [5].

Before presenting further respondent perceptions on the nature of hotspots and the detection probability of current policies, this paper presents an overview of enforcement action data in the Riau and South Sumatra Provinces for land/forest fires by law enforcement actors. Please refer to Tables $3.3 \mathrm{a}$ and 3.3b. Tables $3.3 \mathrm{a}$ and $3.3 \mathrm{~b}$ show a downturn pattern related to the number of hotspots and burning areas in the Riau and South Sumatra Provinces in the 
2015-2017 period, but interestingly, the latest data in the year $2018^{6}$ show a dramatic increase. However, the tables also present a low pattern in the enforcement coverage and monitoring process from the year 2015 until 2017 for the case of land/forest fires. On average, the Police were able to apprehend a suspect in only $8.10 \%$ of hotspot cases in Riau Province and $0.13 \%$ of hotspot cases in South Sumatra Province.

Furthermore, given the higher hotspot occurrence in South Sumatra Province, as shown in Table $3 \mathrm{~b}$, the coverage of punished burning land to the overall burning area based on a court case in South Sumatra is lower compared to Riau Province (Table 3a), with values of $4.41 \%$ compared to $1.09 \%$. However, in the same table, the paper also shows that the court was likely to punish guilty individual suspects and companies that had already been apprehended by the Police in South Sumatra Province compared to Riau Province. The data reveal that the less stringent actual enforcement and low detection probability, especially in South Sumatra Province, highlight the inadequacy of deterrence for environmental offenses. As a result, economic agents do not correctly receive signals not to engage in unsustainable and illegal activities. In the next section, more detail on how enforcement obstacles shape deterrence perceptions is presented.

\footnotetext{
${ }^{6}$ The latest data from SiPongi (Karhutla Monitoring System) show 296 hotspots in Riau Province (an increase of 275\%) and 394 hotspots in South Sumatra Province (an increase of 39\%), $<$ http://sipongi.menlhk.go.id/home/main $>$ as of 01/27/2019.
} 
Table 3a. Enforcement on Land and Forest Fires in Riau Province

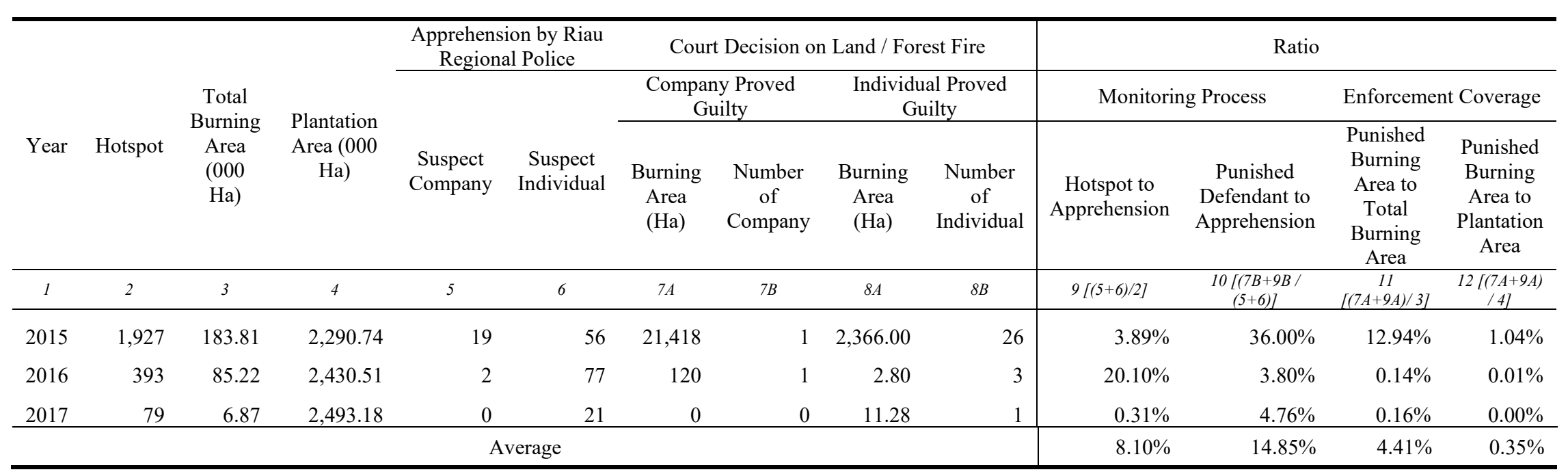

Table 3b. Enforcement on Land and Forest Fires in South Sumatra Province

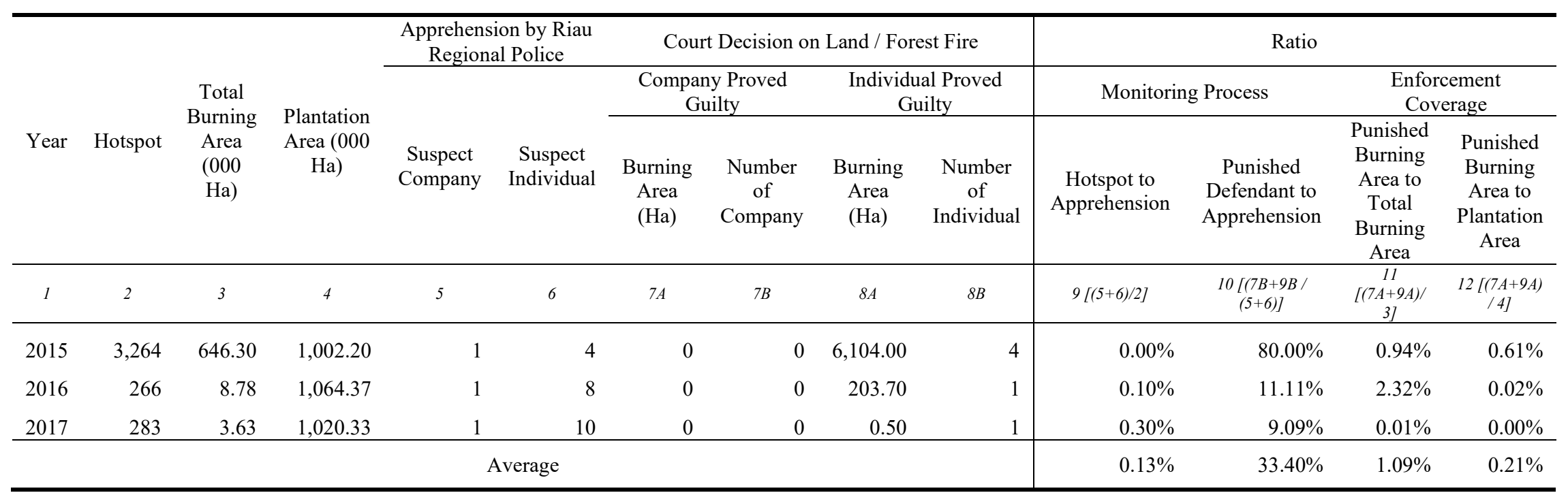




\subsection{The Political Implementation of Regulatory Approaches}

In policy implementation, securing compliance is an essential part to ensure that goals are reached and not thwarted by opponents of the policy. Moreover, compliance depends on whether or not regulators have enough power over others. The more regulatory power required for an action, the more likely it is that an economic agent will comply with a request. As a result, the central principle of political implementation states that implementation outcomes are determined by power [20].

A penalty, as part of the regulatory power in enforcing compliance, which equals a percentage or fraction of the evasion, ultimately reduces the ability to hide noncompliance and therefore improves overall deterrence [24]. However, the inability to execute a penalty as part of a lack of power will hamper the enforcement deterrence.

Three major laws have been enacted in Indonesia to punish the violators in the case of land/forest fire as follows:

1. Law No. 1/1946 on Criminal Law. The defendant will be facing punishment for intentionally causes a fire or explosion faces a minimum of 12 years and a maximum of 20 years imprisonment

2. Environmental Management Law No. 23/1997, which was amended by Law No. 32/ $2009^{7}$ on Environmental Protection Management. The defendant who causes haze pollution and intentionally commits an action that violates the ambient standard will be criminally prosecuted with a minimum punishment of three years and a maximum of 10 years imprisonment as well as a minimum fine of Rp3 billion and a maximum fine of Rp10 billion.

3. Plantation Law No. 18/2004, which was amended and strengthened by Law No. $39 / 2014^{8}$, imposes criminal sanctions through severe fines and sentencing for burning opening plantations. The punishment on the offender who uses the burning method in opening/cultivation plantation land (Art. 108) faces imprisonment for ten years and a maximum fine of Rp10 billion.

The interviewee, a Prosecutor from the Riau High Attorney General Office (D-2RAttorney), explained the existence of obstacles in the execution of environmental recovery fines based on court verdicts, not including detailed regulations in the Act related to the land and forest fire. Furthermore, there are no special arrangements in the case of defendants proposing installments, as part of state debts, for paying environmental recovery costs. The Investigator from the Ministry of Environmental and Forestry (D-3-MinEAF) also strengthened the argument by giving an example:

Investigator: I am using an example from the criminal cases related to a palm oil plantation company that was found guilty by the court. The company was fined RpI billion and required to restore the burning environment at the cost of Rp13 billion or USD916,3319. However, this verdict has become an "advantageous" for the company as a defendant because there is no direct financial mechanism that clearly stated how these fines will be utilized implemented, and as a result, the Rp13 billion restoring cost has never been paid by the company.

In contrast, the Investigator from South Sumatra Local Environmental Agency (D-5SSLocalEA) noted the existence of obstacles in the early stage of the law enforcement process, namely, high political pressure on the Environmental Agency. As a result, the Local Environmental Agency could not independently build law enforcement cases on land/forest fires in South Sumatra Province; rather, they could only provide a monitoring and fire prevention function. Moreover, the Investigator argued that the lack of support and prioritization on land/forest fire cases by the Provincial Government has undermined his role in the South Sumatra Environmental Agency.

\footnotetext{
${ }^{7}$ Law No. 32/2009 tentang Perlindungan dan Pengelolaan Lingkungan Hidup. Government of Indonesia: Jakarta (in Bahasa).

${ }^{8}$ Law No. 39/2014 tentang Perkebunan. Government of Indonesia: Jakarta (in Bahasa).

${ }^{9}$ The Bank of Indonesia transaction exchange rate in June 21, 2019 is 1 USD $=$ Rp14,187.
} 
Furthermore, given the high political and economic costs to the Local Government, the obstacles will also create lower incentives for agriculture development [25], [26]. The Executive Director of Green Trade Initiative (ID-3-EnvNGO) argued that an incentive mechanism must be built in to provide "rewards" for those who are already effectively developing the sustainable palm oil sector. For example, Local Governments that are able to manage highly productive palm oil plantations in their region without fire outbreaks or environmental damage will be rewarded an additional transferable fund (General Allocation Fund $^{10}$ ) from the National Budget. In addition, palm oil companies that maintain proper environmental governance and prevent fire in their concession areas will be given a channel to strengthen their investments or provided with further financing schemes. Commodity governance is still needed as a safeguard to prevent the negative spillover on the environment.

In all, the present study analyzed obstacles to enforcing deterrence and reaching policy goals. Thornton [27] studied deterrence and found that economic agents will reassure their compliance when someone else is caught and penalized. The paper identified insufficient penalty enforcement in the Riau and South Sumatra Provinces, which is critical in the context of building regulatory deterrence. The existence of obstacles to enforcing penalties reflects the inability of law enforcement to send a signal of deterrence not to violate legal procedures and influence compliance. Furthermore, the paper also identified a patronage network that creates failure for the government to uphold effective policies against influential companies who ignore illegal commercial fires. The high pressure and political influence in the region, especially in corporate criminal cases, is one of the reasons that regional investigators are not as strong as investigators from the Police and Central Government Office. This finding is in line with Varkkey [14], who discussed the difficulty of overturning the system of patronage politics. The collusion of local elites and plantation owners at the local level creates a failure to comply with formal legal permit procedures [28].

\subsection{The Regulator Organization Capacity}

The central principle in administrative policy implementation to ensure desired outcomes is through sufficient organizational capacity or resources [23]. Therefore, law enforcement must have adequate financial and political capital support from government agencies to successfully implement regulations. Gajduschek [29] defined regulatory enforcement capacity as the ability of regulatory agencies to deter potential externalities. Furthermore, a normative mechanism that induces compliance through the legitimacy of the person requesting an action is generally sufficient in administrative implementation. However, administrative policy implementation problems may occur because of poor coordination, insufficient resources, or insufficient time [30]. To identify the real obstacles in law enforcement implementation, the interviewees were asked to describe their own experience in their respective offices.

The majority of the respondents indicated insufficient budget resources in the Budget Execution (Allotment) Document ${ }^{11}$ as a challenge in enforcing land/forest fire cases. Moreover, the Investigator from Riau Regional Police (D-1-RPolice) stated that the

\footnotetext{
${ }^{10}$ Law No. 33/2004 defined the General Allocation Fund (DAU) as a Central Government transferable fund to Local Governments from the National Budget, with the aim of equalizing the distribution of financial capacity between regions in Indonesia in the context of decentralization.
}

11 Article 1, Ministry of Finance Decree No. 171/PMK.02/2013 define Budget Execution Document (DIPA) is a budget implementation document prepared by budget user (Government Institution) and served as the base for budget execution or implementation. 
enforcement process is without specific budget allocation but only under a routine budget. However, the Prosecutor from Riau High Attorney General Office (D-2-RAttorney) stated that land/forest fires are treated as individual cases and there is a specific allocation for law enforcement in the Budget Execution (Allotment) Document. However, the expenditure allocation is for the completion of only two land/forest fire cases per year. As a result, given the insufficient budget, the Investigator from Riau Regional Police (D-1-RPolice) and the Forest Campaigner from NGO - Greenpeace (ID-4-EnvNGO) stated that gathering substantial evidence to determine the actor that triggered a land and forest fire is challenging for law enforcement.

The Prosecutor from South Sumatra High Attorney General (D-6-SSAttorney), in line with Budiningsih [4], pointed out that coordination is also a problem in the land/forest fire enforcement process.

Prosecutor: The existence of an egocentricity and lack of coordination between public prosecutors and police investigators have resulted in a limited number of land/forest fire cases prosecuted in the Criminal Court.

There is another point of view when discussing coordination to tackle haze pollution. The Expert Witness (ID-1-ExpertW) argued that establishing a multidoor enforcement coordination approach to handle land/forest fire cases is the key answer due in part to the complexity of cases and the limited capacity of law enforcement, for example, in identifying the extent of a plantation area with an illegal status occupied by plantation companies.

Expert Witness: There was a company that received cultivation right in 2014 but has been operating since the early 1990s. Moreover, there are non-sustainable plantation areas that have been harvested to supply the existing market demand for fresh fruit brunch but only operate with location permits.

In parallel to the multidoor coordination arrangement, the Investigator from the Ministry of Environmental and Forestry (D-3-MinEAF) also indicated the necessity of multidisciplinary knowledge in tackling haze pollution:

Investigator: the economic valuation for the lost benefit in the case of land/forest fires is needed because the burning creates fertile land that is ready to be planted. In addition, the value of the ecological or recovery losses should use an economic valuation to avoid double counting and to increase data accuracy.

In sum, this paper found that the obstacles that shape deterrence were not solely based on political implementation but also emerged from the implementation of administrative policies. The obstacles emanate from budgets and a lack of coordination among law enforcement officers and institutions. Law enforcement interventions involving the deployment of an investigation and prosecution in the case of land and forest fires need more support, especially in terms of financial resources, to avoid deterrence failure among violators. Previous studies have shown that a lack of sufficient financial resources for the enforcement of environmental regulations creates low deterrence [31], [32]. Furthermore, the outcomes of the paper, which include a lack of coordination between law enforcement institutions in South Sumatra Province, extend the study by Budiningsih [4]. The chance of environmental policy violators being caught or punished is reduced by ineffective law enforcement coordination. Moreover, enforcement that creates deterrence is related to not only the severity of penalties but also the probability of detection as a crucial element that drives compliance [33]. 


\subsection{Possible Ways for Strengthening Deterrence with Tax Policy}

Tax as a market-based instrument would be placing a direct cost on environmental damage [34]. Knorring and Welzel [35] showed that compliance with regulatory policies might be improved by punitive taxes. Based on these conditions, the implementation of a strengthened regulatory approach with tax policies and administration ${ }^{12}$ to tackle haze pollution will increase the probability of detection and punishment for violators of the law. Moreover, regulations to hold firms liable for potential damages from their pollution may improve policy compliance [36]. Moreover, the incentive policies are acceptable and create deterrence that mitigates resistance and the unacceptability of environmental management policies.

Furthermore, tax policy is a possible way to link the scale of revenue to the degree of a problem in the Indonesia National Budget (APBN). Maatta [37] stated that environmental taxes are taxes with the primary purpose of generating revenue that also have a significant positive effect on the environment. The ability of tax administrations to identify entities subject to a tax as the underlying structure in tax policy design will increase the strength factors in identifying noncompliant economic agents. As a result, the tax administration will be able to tag personal characteristics ${ }^{13}$, income, and land ownership records from data pool integration ${ }^{14}$ and measure the economic value of the benefits lost to land and forest fires. Based on Crowding Theory, the way a tax administration identifies a taxpayer (as external intervention) has an impact on the taxpayer's behavior (as intrinsic motivation) [38].

\section{Conclusion}

Deterrence emanates from the probability of detection and the severity of sanctions. The in-depth interviews reveal that current regulatory enforcement is still limited in sending a strong signal about the punishment of intentional fire behavior. This paper contributes to the literature through revealing enforcement obstacles that hamper deterrence and create the persistence of haze pollution at South Sumatra and Riau Provinces. The lack of special arrangements for environmental recovery costs and direct financial mechanisms for how fines are to be utilized has hampered the enforcement of deterrence. Moreover, the limited budget and lack of coordination of agencies indicate a low probability of being inspected. As a result, the benefit of noncompliance is relatively high, and noncompliance practice prevails.

\footnotetext{
12 The Presidential Instruction Decree No 16/2011 that amended with No. 11/2015 stated that the Ministry of Finance, as part of the Government Institution, was involved in Controlling Land and Forest Fires. However, the role of the Ministry of Finance is not clearly defined in the supporting process. Moreover, in the Ministry of Environmental and Forestry Decree No. P.32/MenLHK/Setjen/Kum.1/3/2016 for the national level of coordination, the Ministry of Finance and the Directorate General of Taxes are not part of an Organizational Structure.

13 Following Mirrless's concept that the optimal tax depends on the identification of personal characteristics [39], [40].

14 Based on Government Regulation No.31/2012 Government Agencies (Including: National Land Agency and Ministry of Domestic Affairs), Institutions (Including: Bank and Financial Industry), Associations and other agencies must provide data to the Directorate General of Taxes at the Tax Administration.
} 
There are many ways to strengthen regulatory enforcement policies, especially when dealing with substantial political influence. The establishment of policy regimes that include fiscal instruments for environmental management cannot be overlooked as a reference point for the best future solutions. The ability to impose taxes to regulate pollution and generate revenue for the government should be considered, and an improved capacity can enhance the enforcement of haze pollution deterrence in Indonesia. Taking this into account, future research will carefully investigate tax policies that influence environmental management during the implementation stage of the law enforcement process as part of mixed policy instruments for land and forest fires that create persistent haze pollution in Indonesia.

Acknowledgments. We are greatly indebted to Professor Shunji MATSUOKA for encouragement and critical comment on an earlier paper draft. Special thanks to Professor Katsuya Tanaka, Shiga University, for the thoughtful comment and insightful advice on the draft. We also acknowledge the Haraguchi Memorial Asia Research Fund for sponsoring the field research in Indonesia.

\section{References}

[1] Greenpeace.: The Final Countdown: Now or Never to Reform the Palm Oil Industry. Research Report. Greenpeace International (2018).

[2] Sheil, Douglas., Anne Carson., Erik Meijaard., Meine van Noordwijk., Joanne Gaskel., Jacqui Sunderland-Groves., Karah Wertz., \& Markku Kannien.: The Impacts and Opportunities of Palm Oil in Southeast Asia. Occasional Paper-CIFOR, 51 (2009).

[3] Lee, Janice Ser Hua Lee., Sinan Abood., Jaboury Ghazoul., Baba Barus., Krystof Obidzinki., \& Lian Pin Koh.: Environmental Impacts of Large-Scale Oil Palm Enterprises Exceed of Smallholdings in Indonesia. Conservation Letter, 7(1), 25-33(2013).

[4] Budiningsih Kushartati.: Implementasi Kebijakan Pengendalian Kebakaran Hutan dan Lahan di Provinsi Sumatera Selatan (in, Bahasa). Jurnal Analisis Kebijakan Kehutanan, 14 (2), 165-186 (2017).

[5] Anderson, Z. R., Kuster, K., Mccarthy, J., Obidzinski, K.: Green Growth Rhetoric Versus Reality: Insight from Indonesia. Global Environmental Change, 38, 30-40 (2016).

[6] Miettinen, J., Chenghua Shi., SC, Liew.: Two Decades of Destruction in Southeast Asia's Peat Swamp Forests. Frontier in Ecology and the Environment, 10 (3), 124-128 (2012).

[7] Gaveau, DLA., MA Salim., K Hergoualc'h., B Locatelli., S Sloan., M Wooster., ME Marlier., E Molidena., H Yaen., R DeFries., L Verchot., D Murdiyarso., R Nasi., P Holmgren., \& D Sheil.: Major Atmospheric Emissions from Peat Fires in Southeast Asia During Non-Drought Years: Evidence from the 2013 Sumatran Fires. Sci. Rep, 4, 6112 (2014).

[8] Lestari, RK., M Watanabe., Y Imada., H Shiogama., RD Field., T Takemura., \& M Kimoto.: Increasing Potential of Biomass Burning Over Sumatra, Indonesia Induced by Anthropogenic Tropical Warming. Environ. Res. Lett, 9 (10), 1-7 (2014).

[9] Hu, Yuqi., Nieves Fernandez-Anez., Thomas E. L. Smith., and Guillermo ReinA.: Review of emissions from smouldering peat fires and their contribution to regional haze episodes. International Journal of Wildland Fire, Vol. 27, 293-312 (2018).

[10] Page, Susan E., Agata Hoscilo, Andreas Langner, Kevin Tansey, Florian Siegert, Suwido Limin, Jack Rieley.: Tropical Peatland Fires in Southeast Asia, Springer, pp. 263-287 (2007). 
[11] Wilson D, Dixon SD, Artz RR, Smith TE, Evans CD, Owen HJ, Archer E, Renou-Wilson F.: Deviation of greenhouse gas emission factors for peatlands managed for extraction in the Republic of Ireland and the United Kingdom. Biogeosciences 12, 5291-5308 (2015).

[12] ASEAN.: ASEAN Agreement on Transboundary Haze Pollution. The ASEAN Secretariat (2016).

[13] Iskandar, Deden Dinar. Ph.D. dissertation. Center for Development Research, University of Bonn. Germany (2012).

[14] Varkkey, Helena.: The Haze Problem in Southeast Asia: Palm Oil and Patronage. New York: Routledge Abingdon (2016).

[15] Paternoster, R., R Bachman., R Brame., \& L W Sherman.: Do Fair Procedures Matter? The Effect of Procedural Justice on Spouse Assault. Law and Society Review, 31(1),163-204 (1997).

[16] World Bank.: Governance and Development. Research Report: The International Bank for Reconstruction and Development/World Bank (1992).

[17] Dasgupta, P.: Economic Progress and the Idea of Social Capital. In P Dasgupta and I Serageldin (Eds.), Social Capital: A Multifaced Perspective. Washington, DC: World Bank (2000).

[18] Simorangkir, Dicky., Sumantri.: A Review of Legal, Regulatory, and Institutional Aspects of Forest and Land Fires in Indonesia. Research Report: Project FireFight South East Asia (2002).

[19] Carmenta, R., Aiora Zabala., Willy Daeli., \& Jacob Phelps.: Perceptions Across Scales of Governance and the Indonesia Peatland Fires. Global Environmental Change, 26, 50-59 (2017).

[20] Matland, R, E.: Synthesizing the Implementation Literature: The Ambiguity-Conflict Model of Policy Implementation. Journal of Public Administration Research and Theory, 5 (2), 145-174 (1995).

[21] Game E, T., Meijaard E., Sheil D., \& Mcdonald-Madden E.: Conservation in a Wicked Complex World: Challenges and Solutions. Conservation Letter, 7, 271-277 (2014).

[22] Reed, J., Van Vianen J., Deakin EL., Barlow J., \& Sunderland T.: Integrated Landscape Approaches to Managing Social and Environmental Issues in the Tropics: Learning from the Past to Guide the Future. Global Change Biology, 22, 2540-2554 (2016).

[23] Lo, Carlos Wing-Hu., Gerald E Fryxell., \& Wilson Wai-Ho Wong.: Effective Regulations with Little Effect? The Antecedents of the Perceptions of Environmental Official on Enforcement Effectiveness in China. Environmental Management, 38 (3), 388-410 (2006).

[24] Gupta SA.: Determinants of Tax Revenue Efforts in Developing Countries. Research Report. IMF Working Paper (2007).

[25] Potter, Lesley M.: Alternative Pathways for Smallholders Oil Palm in Indonesia: International Comparisons, The Oil Palm Complex: Smallholders, Agribusiness, and State in Indonesia and Malaysia. Singapore: NUS Press (2016).

[26] McCharty J, F., Gillespie P., \& Zen Z.: Swimming Upstream: Local Indonesia Production Networks in "Globalized" Palm Oil Production. World Development, 40 (3), 555-569 (2012).

[27] Thornton, Dorothy., Neil Gunningham., \& Robert A Kagan.: General Deterrence and Corporate Environmental Behaviour. Law and Policy, 27(2), 262-288 (2005).

[28] Environmental Investigation Agency.: Permitting Crime: How Palm Oil Expansion Drives Illegal Logging in Indonesia. London: EIA. (2014).

[29] Gajsduschek, Gyorgy.: Measuring Cross-Sectional Law Enforcement Capacity of Regulatory Agencies in Hungary. Transylvanian Review, 44, 108-125 (2015).

[30] Etzioni, Amitai.: Complex of Organizations: A Sociological Reader. New York: Holt, Rinehart, and Winston.

[31] Sparrow, M, K. (2008). The Character of Harms: Operational Challenges in Control. Cambridge: Cambridge University Press (1961). 
[32] Kagan, R., Gunningham N., Thornton D.: Explaining Corporate Environmental Performance: How Does Regulation Matter? Law and Society Review, 37, 51-89 (2003).

[33] Cohen, MA.: Empirical Research on the Deterrent Effect of Environmental Monitoring and Enforcement. Environmental Law Reporter, 30(4), 10245-10252 (2000).

[34] OECD.: The Polluter Pays Principle, OECD, France(1975).

[35] Knorring, E. v., and Welzel, P.: "Effiziente Umweltauflagen durch abgabenorientierte Sanktionierung?" Zeitschrift für Umweltpolitik und -recht, 21, 341-358 (1998).

[36] Bohm, Peter., \& Cliffrod S. Russel.: Comparative Analysis of Alternative Policy Instrument. In Allen V. Kneese \& James L. Sweeney (Eds.), Handbook of Natural Resources and Energy Economics (pp. 395-460). New York: North-Holland (1985).

[37] Maatta, K.: Environmental Taxes: An Introductory Analysis. Cheltenham: Edward Elgar (2006).

[38] Frey, Bruno S., \& Lars, P, Feld.: Deterrence and Morale in Taxation: An Empirical Analysis, Working Paper 760: CESIFO (2002).

[39] Mirrlees, James A.: An Exploration in the Theory of Optimal Income Taxation. Review of Economic Studies, 38, 175-208 (1971).

[40] Akerlof, George.: The Economics of 'Tagging' as Applied to the Optimal Income Tax, Welfare Programs, and Manpower Planning. American Economic Review, 68(1) (1978). 